DOI: $10.22363 / 2312-8127-2018-10-4-393-402$

\title{
Characteristics of Chinese economy in 2000-2016: economic growth sustainability
}

\author{
E.N. Moiseeva \\ National Research University Higher School of Economics \\ Faculty of World Economy and International Affairs \\ School of Asian Studies \\ 17 Malaya Ordynka St., bldg. 1, Moscow, 119017, Russia
}

The aim of the research is to determine through the historical perspective the reasons of China's economic slowdown in 2000-2016 and using historical data to find out whether it is possible to return to the high rates of economic growth or at least to sustain the current GDP growth rates in between $6-7 \%$. The hypothesis is that China is unable to return to the doubledigit economic growth rates or even to sustain the current GDP growth rates in the long or shortterm. The hypothesis will be proved through mixed methodology with the implementation of descriptive and historical research designs, which involve collection, verification, and synthesis of evidence from the period since 2000-s and up to the present moment.

Key words: China's economic slowdown, party-state, economic restructuring, innovations, costs competitiveness, cheap labor force

\section{Introduction}

Since the end of the 20th century, China embraced industrialization and modernization, which resulted in the economic growth. The economic reform and opening up of the main ideologist of changes, Deng Xiaoping enabled China to conduct a transition from a totalitarian party-state to a post-totalitarian with the division of political and economic dimensions. The elements of the market economy were introduced while China still remained a communist state with strict command and administration system. The country reached tremendous economic progress within the past 40 years; since late 1970-s China's economic system has evolved, the dynamic growth of the Chinese economy has led to the increase of standards of leaving of the biggest part of population; developed a respectful second place in the list of the world's most powerful economies. At the same time, the years of spectacular economic progress did not resolve and in some cases only worsened the burning issues concerning manufacturing overcapacity, excessive real-estate sector, rising production costs, inequality, corruption, environmental imbalances, inadequate technological innovation, etc. Moreover, although the Chinese economy 
was flourishing in the short-term, it has been insufficient to ensure sustainable longterm growth. The reasons of the economic slowdown derive from the problems that were slowly accumulated since the new economic model was introduced. This paper will be concentrated on the problems that took a turn for the worse in the last decade.

\section{Macroeconomic characteristics of the Chinese economy}

Chinese economy is the second largest in the world; however, in terms of GDP per capita, PPP, it is only on the 80th place, one of the reasons for such a misbalance is China's large population.

Since the beginning of the 21st century and up to 2007, the Chinese economy was dynamically growing and showed high GDP growth rates of $14 \%$ in its maximum point. The main source of growth derived from the strict redistribution of the resources by the party-state and control over cheap labor force. China has become the global manufacturer and the world's largest importer due to its main competitive advantage - low production costs. However, after the period of growth, the first indicators for the slowdown emerged in 2008 during the Global crisis when the Chinese export decreased due to the global fall in demand. Since that time Chinese economy is facing downturn; in 2016 it showed its slowest dynamics $6,7 \%$ (see Chart 1) [1].

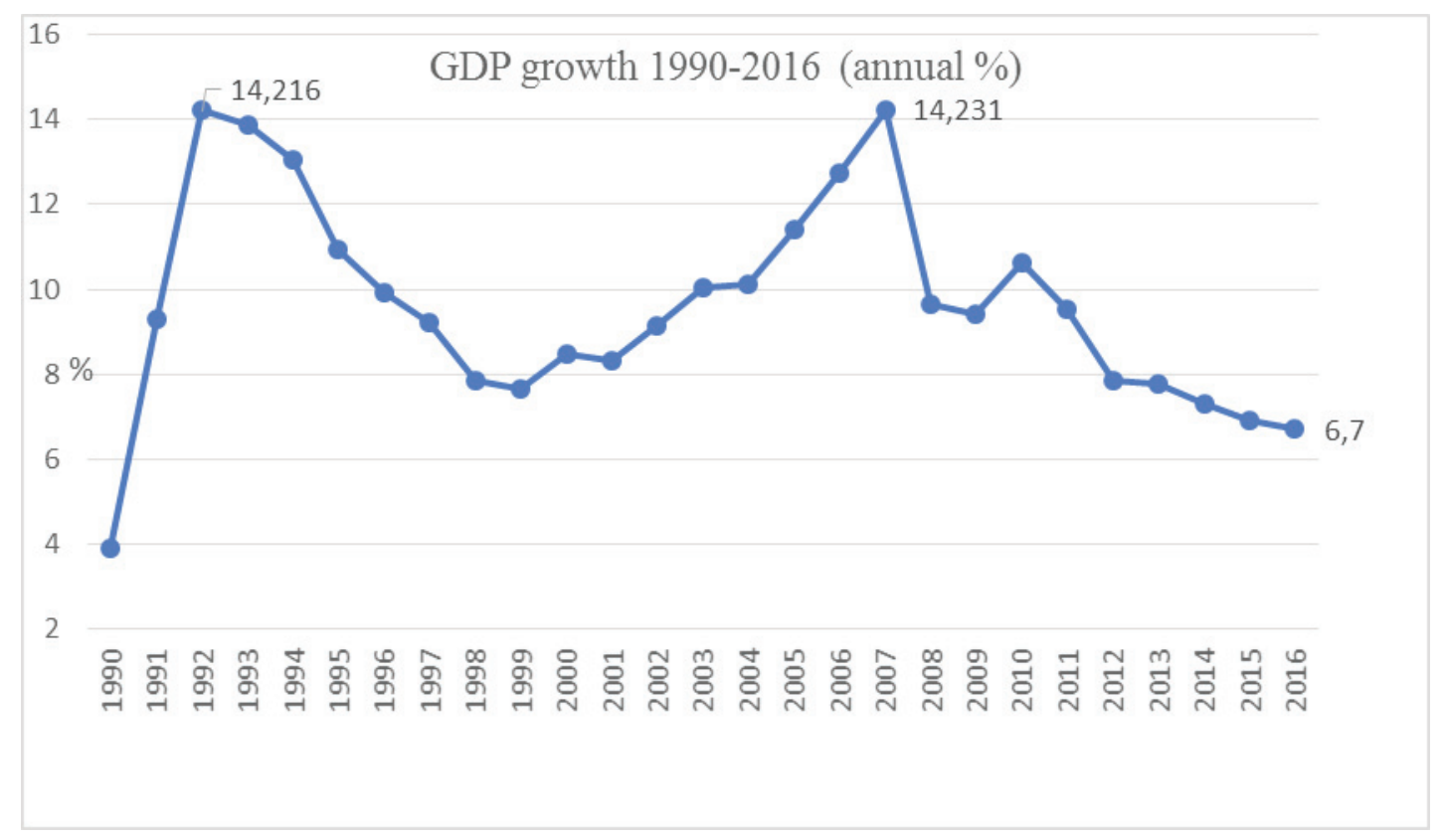

Chart 1. Annual GDP growth in China (1990-2016) [2]

The exports and imports also diminished: the export volumes dropped from $37 \%$ of GDP in 2006 to $18 \%$ in 2016, while import volumes decreased from $28 \%$ 
in 2006 to $18 \%$ in 2015 (See Chart 2 and Chart 3). Simultaneously, manufacturing and construction industry is slowing down following the fall in demand for basic materials [3].

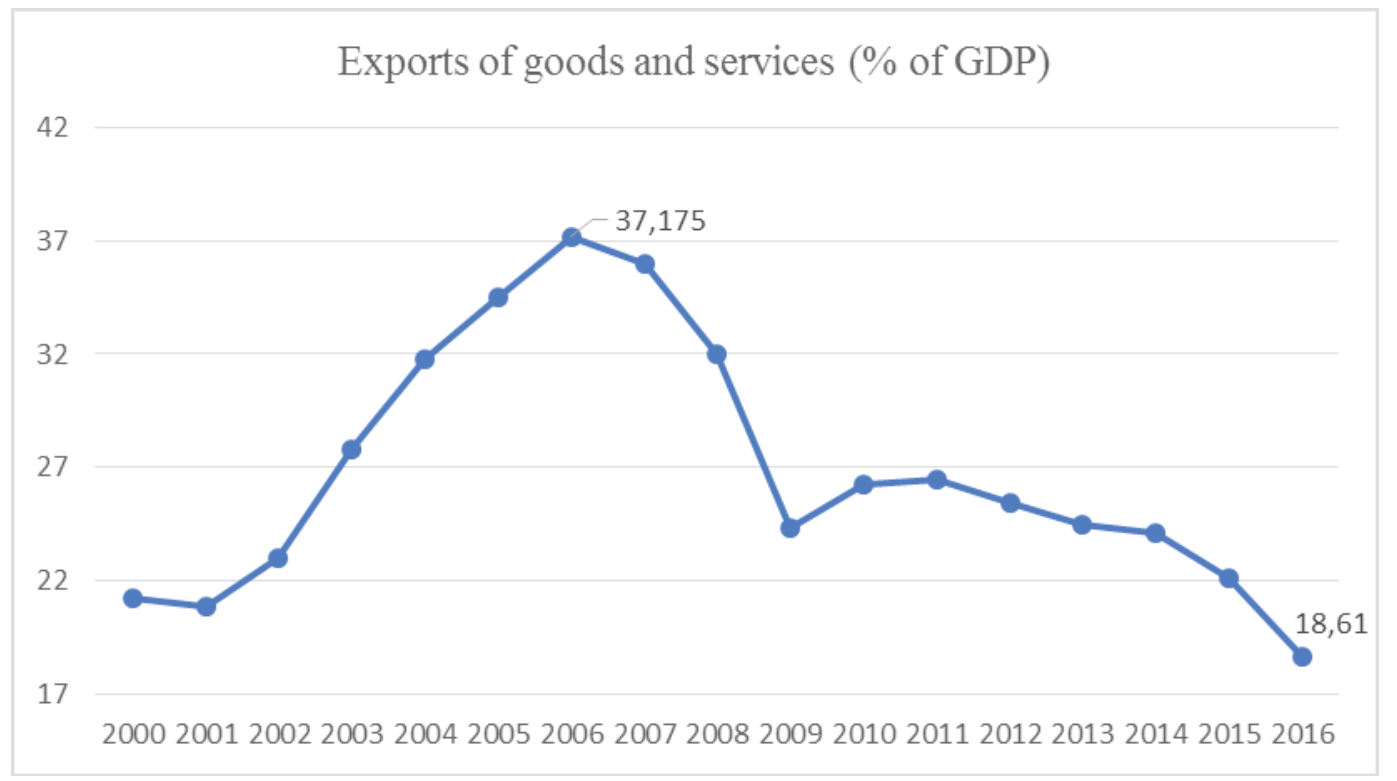

Chart 2. Chinese exports of goods and services (2000-2016) [4; 5]

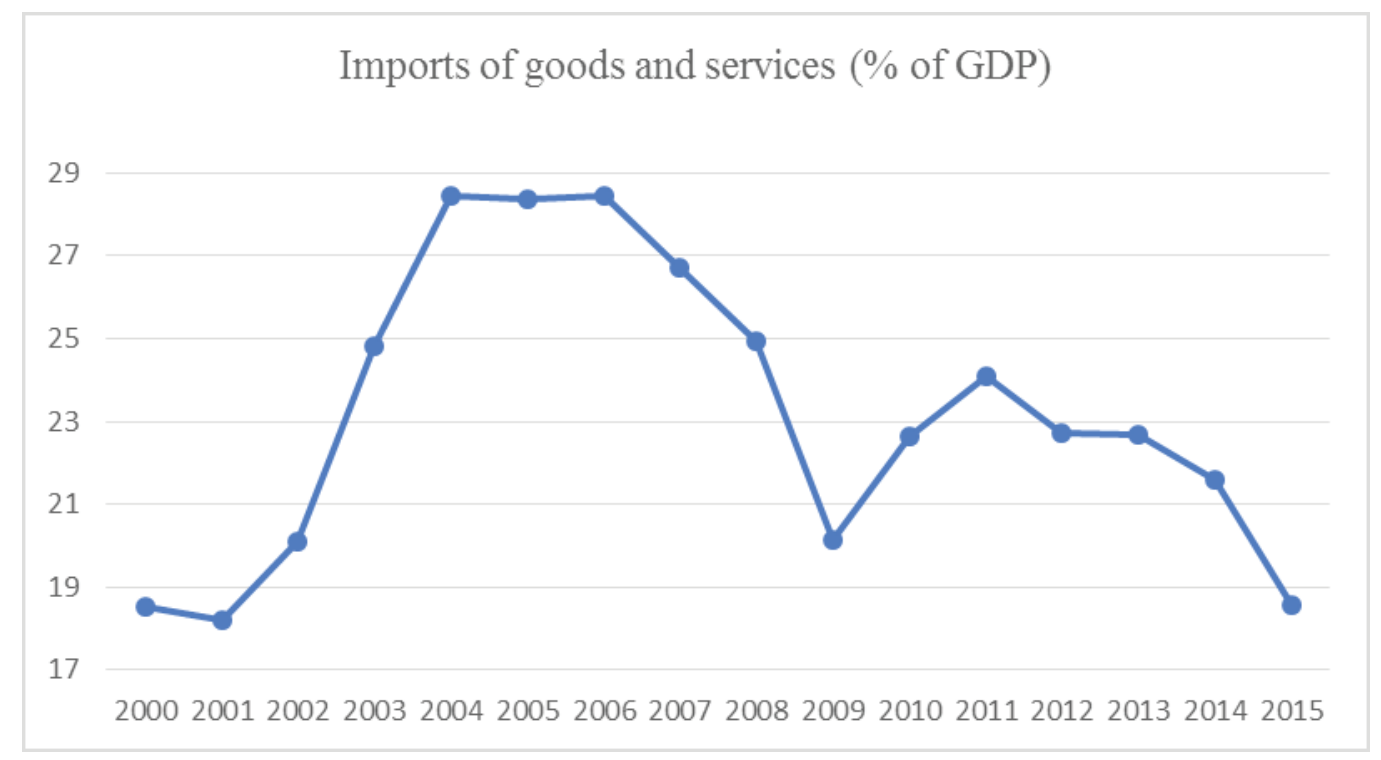

Chart 3. Chinese imports of goods and services (2000-2016) [6] 
In addition to that, Chinese economy encounter rapid decrease of foreign exchange reserves which is the consequence of the Governmental policy to support weak yuan and ease up the economic slowdown by credit fueling. Foreign exchange reserves reached its minimum volumes since 2010 and continue to vanish [7]. The total debt of China at the end of 2016 equaled $277 \%$ of GDP, which creates major financial risks [8]. The policy of accumulation debt and supporting economy, using credits is a dangerous policy that may have serious consequences.

In total, Global crisis occurrence showed the economic problems that were hidden, but emerged after the crisis struck; so that the Global crisis opened the weakest spots in the Chinese economy.

\section{Reasons for the economic slowdown}

The driving force for the Chinese economic acceleration was investment in heavy industries, capital-intensive industries (infrastructure, real estate, etc.). However, the economic boom was reached at the cost of consumption and labor income growth. While financing heavy industrial sector and not boosting investments into services, the consumption of households as a share of GDP contracted (see Chart 4).

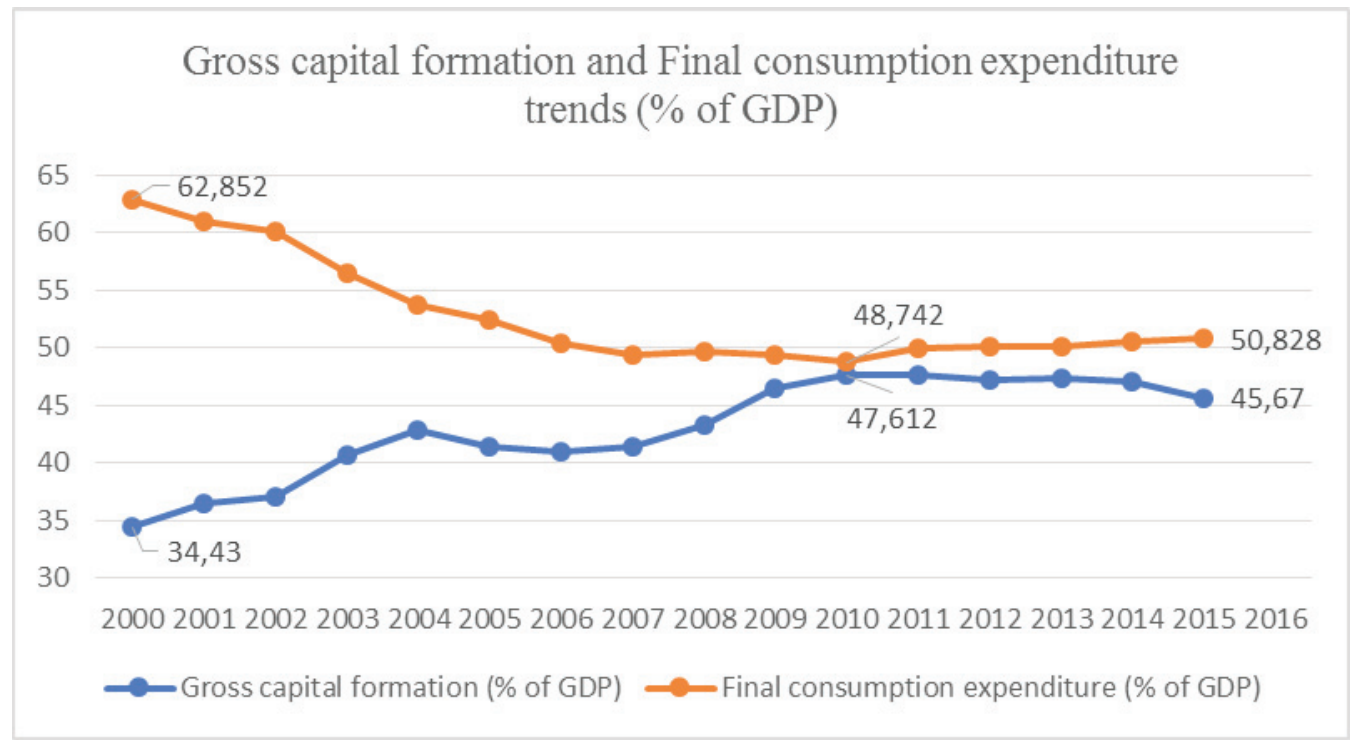

Chart 4. Relation of Gross capital formation and Final consumption expenditure $[9 ; 10]$

The reason for the phenomenon of negative investment-consumption correlation may lie in preferential credit policy of heavy sector and abandoning light sector. The Government have chosen the strategy of heavy industries promotion; the local authorities in provinces followed the instructions from the center and have directed the long-term bank loans to heavy industries as well. Companies in 
the heavy sector are capital-intensive large firms; they are less productive and flexible than small businesses, which are more oriented on short-term investment projects in light sector. While giving massive credits to large companies for medium- and longterm investment projects, short-term loans for small businesses were abandoned. Moreover, the Chinese Government was predominantly supporting state-owned enterprises (SOEs) and public entities, while skipping private enterprises. And all these practices are repeated today.

Although macroeconomic reforms were implemented at the end of the 20th century, the Chinese Government have not yet introduced essential changes in the microeconomy. Private businesses were and are still controlled by the partystate and are not supported by the Government. Moreover, microeconomy and financial sphere is the object of Government interference, which negatively affects the overall development of the economy. It is important to sustain growth on the microlevel of private enterprises and give them freedom, as they are able to push the economic growth. The same with the household consumption: without private businesses' and households' flourishing, it is impossible for the economy to sustain stable development.

\section{Innovations in Chinese economic growth}

Another important issue that restrains Chinese economic growth is inappropriate innovation. Innovation is one of the key drivers of the economy; it may become the curing power for the Chinese economy. According to Bloomberg Innovation Index 2017, China, however, is on the 21 st position among the world's most innovative economies; the rating is not good enough for the second largest economy in the world [11].

\section{R\&D expenditure (\% of GDP)}

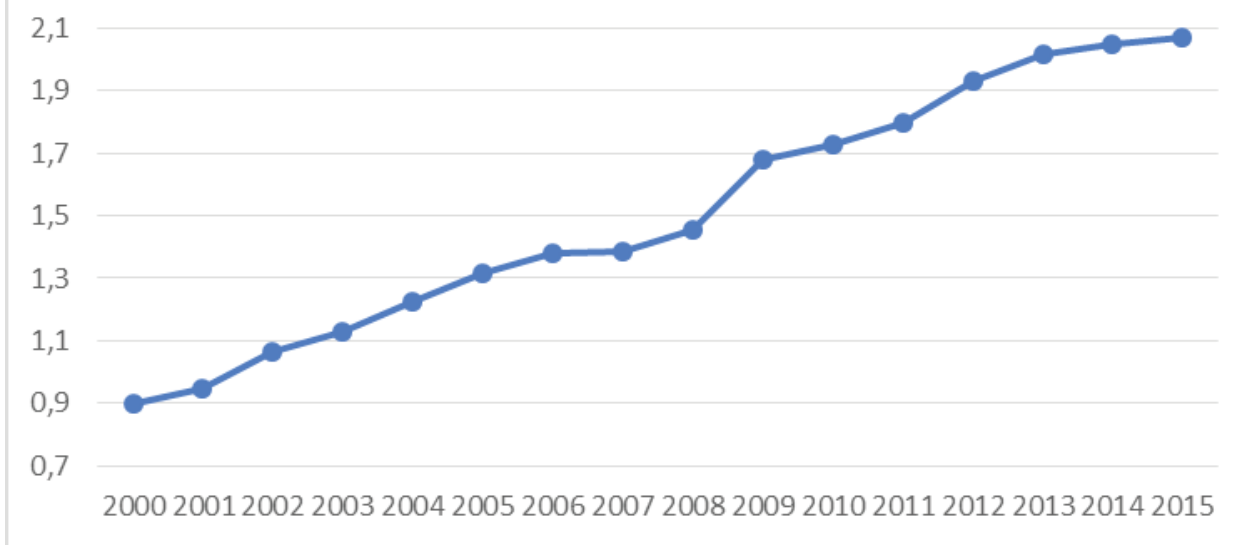

Chart 5. R\&D expenditure in China (\% of GDP) [18; 19] 
China is the number one state in terms of manufacturing, it ranks first in 2016 Global Manufacturing Competitiveness Index (GMCI), and is holding this position since 2010 [12]. China is a manufacturing giant and its competitive advantage derives from workforce productivity, supplier network, and cost competitiveness [13]. Nevertheless, although Chinese manufacturing sector is huge, much of its manufacturing products are low-tech (one-third of Chinese exports are manufactured goods that require low skill and technology intensity) [14; 15]. In case taken the competitive drivers that support China in manufacturing, the weakest ones are legal and regulatory environment; energy policy and innovation policy and infrastructure [16].

Nevertheless, China is gradually increasing investments in R\&D and improving the innovative competitiveness in manufacturing (Chart 5). In 2015 China spent $2,067 \%$ of its GDP on R\&D which is higher than the spending of EU on R\&D $(1,954 \%)$ and a little lower than R\&D expenditure of all the members of Organization for Economic Co-operation and Development (OECD, 2,403\%) [17].

However, extension of innovations may need more capital investments, which will definitely lead to the rise of manufacturing costs and this may result in the fact that China's global manufacturer's status may be changed, the production of manufactured goods will be more expensive. China is shifting towards higher value and more technologically advanced manufacturing, which is healthy for Chinese economy. But at the same time with this switch, China may lose the number one position in terms of global cost competitiveness - this is the price for becoming innovative.

\section{Ecological issues in China and their interdependence with economy}

One of the most pressing challenges that China currently faces is environmental crisis in urban areas. Rapid industrialization that began at the end of the 20th century caused a big issue, which is air, water and soil pollution that is difficult to tackle nowadays. Although a few decades ago, the development of industry was top priority and few people were concerned about the consequences of industrialization, today Chinese society and Chinese Government are on alert. According to Pollution Index 2017 China ranks 6th in the list of the most polluted countries and the state is on the 1st position for carbon dioxide emissions in the world [20;21]. Air pollution is going to become worse as due to population growth and rapid urbanization, energy demands are increasing and there is need for powering new manufacturing and industrial centers. Many of Chinese major cities are not meeting international health standards for the air quality while industrial plants are continuing to exceed the emission norms. Chinese cities lack strict unified regulations of carbon emissions as well as pollution control equipment and energy-saving technologies. The solution for environmental crisis may be found in high technologies and innovations, development of alternative energy sources and strengthening of health standards for workers of industries. 
Pollution is one of the factors that activates the Chinese population's discontent; due to which the authority of the regime may be damaged. Labor disputes, forced demolitions, land acquisitions and pollution are the main causes of public protests [22]. Moreover, annual cost of pollution accounts for $9.7 \%$ of GDP as it damages human capital and natural resources [23]. That is why the Government is highly interested in easing the ecological situation in large cities. As firstly, it will prevent social unrest movements, and secondly, it will enable to improve the economic sustainability through innovations.

\section{Reforms}

The Chinese Government acknowledges that there are problems in the Chinese economy. Moreover, certain measures are implemented to solve those issues. In November 2015, for example, the new 13th 5-year plan was announced by Xi Jinping, the plan included the earlier declared ideas of economic development. The 5-year plan covers the period from 2016 to 2020; according to the proposed plan, China needs to dismiss industrial overcapacity and optimize industrial structure, undergo economic transformation and switch to an innovation-driven economy, improve the environment and enhance quality and efficiency. Education will be improved through allowing the migrant workers from the rural areas to enjoy all the benefits that the urban population has (now around 55\% of the Chinese population lives in cities, however, working migrants are denied the status of the official residents, they do not have equal education and are limited from the employment rights and social security services) [24]. The plan is aimed to ease poverty in rural areas and provide the village population with adequate infrastructure, education, healthcare and public services [25]. In addition, the one-child policy that was initiated in 1979 was abolished and the couples both in rural and urban families are allowed to have two children - it will balance the population, resolve the problem of population aging and support development.

The measures are aimed to create the conditions for a transition from an export-oriented investment-driven economy of growth to the consumption-driven, innovation-centered economy of development. This transition has already been initiated, so that China is gradually developing its innovative capacities and enhancing the quality of citizens' lives. With the switch to an economic development model, the wages are raised, the Chinese "middle class" is expanding; the innovative and green manufacturing is established. All this demands high investments and deep restructuring which effects the Chinese economy and results in a slowdown.

The competitive advantage that fueled the Chinese economy, namely, cheap labor force and low production costs, is vanishing, as the unqualified cheap labor force is replaced by qualified professional workers. The innovations in the economy and resolution of the environmental issues lead to the rise of the production costs. Chinese economy is making qualitative changes with the loss of quantitative rates. 
Conclusion. As the Chinese economy is moving towards the progressive path and its qualitative characteristics are improved, it may be stated that the quantitative figures are affected and further slowdown of the Chinese economy is inevitable, it is the result of the accumulated problems in the economy and simultaneous economic restructuring. And even if the issues concerning unbalance economy, corruption, minor support of private businesses will be solved, Chinese economy still may not sustain the current GDP growth rates. As with the shift to a new model of development, the GDP growth should become lower, but at the same time more stable and sustainable. So, the slowing down of the economic growth is not a problem, as, for example, the Asian Tigers economies (South Korea, Taiwan, Hong Kong and Singapore) had the annual growth (in 2016) not higher than 3\%, but these rather low figures did not prevent the economies to flourish [26]. For China, it would be even more beneficial to provide stable economic growth as one of the main components of economic development.

(C) Moiseeva E.N., 2018

\section{BIBLIOGRAPHY}

[1] 2016 nián guó mín jīng jì shí xiàn “shí sān wǔ” liáng hăo kāì zhōng huá rén mín gòng hé guó guó jiā tǒng jì jú。 [A Good Start for 2016 Implementation of 13th Five-Year Plan on the National Economy. National Bureau of Statistics of the People's Republic of China.] 20.01.2017. URL: http://www.stats.gov.cn/tjsj/zxfb/201701/t20170120_1455942.html

[2] GDP growth (annual \%). China. World bank. 2015. URL: http://data.worldbank.org/ indicator/NY.GDP.MKTP.KD.ZG?end=2015\&locations=CN\&start=1990.

[3] Gabriel Wildau. China import decline reflects manufacturing weakness. Financial times. 08.12.2015 URL: https://www.ft.com/content/4a01cc1c-9d60-11e5-bfed-a24713ecdd4f.

[4] Exports of goods and services (\% of GDP). China. World Bank. 2015. URL: http://data. worldbank.org/indicator/NE.EXP.GNFS.ZS?end=2015\&locations $=$ CN\&start=2000.

[5] China: Share of exports in gross domestic product (GDP) from 2006 to 2016. Statista. 2016. URL: https://www.statista.com/statistics/256591/share-of-chinas-exports-in-grossdomestic-product/.

[6] Imports of goods and services (\% of GDP). China. World Bank. 2015. URL: http://data. worldbank.org/indicator/NE.IMP.GNFS.ZS?end=2015\&locations=CN\&start=2000.

[7] Anthony Dass. More controls in China's complex economy. 06.02.2017. URL: http:// www.thestar.com.my/business/business-news/2017/02/06/more-controls-in-chinascomplex-economy/.

[8] Kevin Yao, Elias Glenn. China GDP beats expectations but debt risks loom. The Reuters. 20.01.2017. URL: http://www.reuters.com/article/us-china-economy-gdpidUSKBN15406C.

[9] Gross capital formation (\% of GDP). China. World Bank. 2015. URL: http://data. worldbank.org/indicator/NE.GDI.TOTL.ZS?end=2015\&locations $=$ CN\&start $=2000$.

[10] Final consumption expenditure, etc. (\% of GDP). China. World Bank. 2015. URL: http://data.worldbank.org/indicator/NE.CON.TETC.ZS?end=2015\&locations $=$ CN\&sta $\mathrm{rt}=2000$. 
[11] Bloomberg Innovation Index 2017. Bloomberg Markets. URL: https://www.bloomberg. com/news/articles/2017-01-17/sweden-gains-south-korea-reigns-as-world-s-mostinnovative-economies.

[12] 2016 Global Manufacturing Competitiveness Index. Deloitte. 2016. URL: https:// www2.deloitte.com/global/en/pages/manufacturing/articles/global-manufacturingcompetitiveness-index.html

[13] Global manufacturing competitiveness index. Deloitte. Country rankings and drivers. 2016. URL: https://www2.deloitte.com/us/en/pages/manufacturing/articles/globalmanufacturing-competitiveness-index.html.

[14] Peter Coy. The Bloomberg Innovation Index. The Bloomberg. 2014. URL: https://www. bloomberg.com/graphics/2015-innovative-countries/.

[15] 2016 Global Manufacturing Competitiveness Index. Deloitte Touche Tohmatsu Limited (DTTL) Global Consumer \& Industrial Products Industry Group and the Council on Competitiveness. 2016. P. 45. URL: https://www2.deloitte.com/content/dam/Deloitte/ global/Documents/Manufacturing/gx-global-mfg-competitiveness-index-2016.pdf.

[16] 2016 Global Manufacturing Competitiveness Index. Deloitte Touche Tohmatsu Limited (DTTL) Global Consumer \& Industrial Products Industry Group and the Council on Competitiveness. 2016. P. 18. URL: https://www2.deloitte.com/content/dam/Deloitte/ global/Documents/Manufacturing/gx-global-mfg-competitiveness-index-2016.pdf.

[17] Gross domestic spending on R\&D. OECD. 2015 URL: https://data.oecd.org/rd/grossdomestic-spending-on-r-d.htm

[18] Gross domestic spending on R\&D. OECD. 2016. URL: https://data.oecd.org/rd/grossdomestic-spending-on-r-d.htm.

[19] Research and development expenditure (\% of GDP). World Bank. 2014. URL: http:// data.worldbank.org/indicator/GB.XPD.RSDV.GD.ZS? end $=2014 \&$ locations $=\mathrm{CN}$ US\&start $=2000$.

[20] Pollution Index for Country 2017. Numbeo. 2017. URL: https://www.numbeo.com/ pollution/rankings_by_country.jsp?title $=2017$

[21] CO2-emissions. Global Carbon Atlas. URL: http://www.globalcarbonatlas.org/en/CO2emissions.

[22] Hou Liqiang. Report identifies sources of mass protests. China Daily. 04.09.2014. URL: http://www.chinadaily.com.cn/china/2014-04/09/content_17415767.htm.

[23] Sharmin Mossavar-Rahmani, Jiming Ha, Maziar Minovi, Matheus Dibo. China's Great Dilemma. Goldman Sachs Investment Strategy Group. 01.2016. P. 37. URL: http://www. goldmansachs.com/what-we-do/investment-management/private-wealth-management/ intellectual-capital/isg-china-insight-2016.pdf.

[24] Zhang Jianfeng. Xi expounds on guideline for 13th Five-year Plan. 11.03.2015. URL: http://english.cntv.cn/2015/11/03/ARTI1446559744633822.shtml.

[25] Highlights of proposals for China's 13th Five-Year Plan. Xinhuanet. 11.04.2015. URL: http://news.xinhuanet.com/english/photo/2015-11/04/c_134783513.htm.

[26] List of Countries by Projected GDP Growth. Statistics Times. 16.12.2016. URL: http:// statisticstimes.com/economy/countries-by-projected-gdp-growth.php. 


\title{
Особенности экономики КНР в период с 2000 по 2016 гг.: устойчивость экономического роста
}

\author{
Е.Н. Моисеева \\ Школа востоковедения \\ Факультет мировой экономики и мировой политики \\ Национальный исследовательский университет \\ «Высшая школа экономики» \\ Малая Ордынка ул., 17, стр. 1, Москва, Россия, 119017
}

Цель данной работы - на основе исторических данных выявить причины замедления темпов экономического роста КНР в период с 2000 по 2016 гг,, а также, используя статистику прошлых лет, выяснить, возможно ли вернуться к высоким темпам экономического роста или же сохранить текущие показали роста ВВП в пределах 6-7\%. Автор работы полагает, что Китай не способен вернуться к высоким темпам экономического роста или сохранить имеющиеся показатели в долгосрочной или краткосрочной перспективе. Данная гипотеза будет подтверждена применением описательного и исторического методов исследования, которые включают в себя сбор, проверку и синтез информации в период с 2000 г. и по настоящее время.

Ключевые слова: замедление экономического роста Китая, партия-государство, экономическая реструктуризация, инновации, дешевая рабочая сила

\section{Информация об авторе / Information about the author}

Моисеева Елизавета Николаевна, магистрант Школы востоковедения факультета мировой экономики и мировой политики Национального исследовательского университета «Высшая школа экономики».

Elizaveta Moiseeva, master student in National Research University Higher School of Economics Faculty of World Economy and International Affairs, School of Asian Studies

E-mail: elizaveta.moiseeval@mail.ru

\section{Для цитирования / For citations}

Моисеева Е.Н. Особенности экономики КНР в период с 2000 по 2016 гг.: устойчивость экономического роста (Eng) // Вестник Российского университета дружбы народов. Серия: Всеобщая история. 2018. Т. 10. № 4. С. 393-402. DOI: 10.22363/2312-8127-201810-4-393-402

Moiseeva E.N. Characteristics of Chinese economy in 2000-2016: economic growth sustainability. RUDN Journal of World History. 2018. 10(4): 393-402.OI: 10.22363/23128127-2018-10-4-393-402

Рукопись поступила в редакцию / Article received: 17.03.2018 